\title{
Forest Structure, Nutrients, and Pentaclethra macroloba Growth after Deforestation of Costa Rican Lowland Forests
}

\author{
Daniela J. Shebitz and William Eaton \\ School of Environmental and Life Sciences, Kean University, Union, NJ 07083, USA \\ Correspondence should be addressed to Daniela J. Shebitz; dshebitz@kean.edu
}

Received 6 March 2013; Accepted 26 March 2013

Academic Editors: S. Liu and D. Pimentel

Copyright (C) 2013 D. J. Shebitz and W. Eaton. This is an open access article distributed under the Creative Commons Attribution License, which permits unrestricted use, distribution, and reproduction in any medium, provided the original work is properly cited.

\begin{abstract}
Succession following deforestation in Neotropical forests has been investigated extensively, yet rarely have studies connected nutrient dynamics with vegetation. This study was conducted in lowland wet forests of Maquenque, Costa Rica. The objectives were (1) to compare carbon $(\mathrm{C})$, nitrogen $(\mathrm{N})$, and phosphorus $(\mathrm{P})$ characteristics and understory vegetation diversity between regenerating forests and primary forests; and (2) to use these variables to evaluate $P$. macroloba's successional role. Four $300 \mathrm{~m}^{2}$ plots were established in primary and secondary forests where $P$. macroloba was the dominant N-fixing tree. Soil and vegetation data were collected from 2008 to 2010 . Values of indicators of C, N, and P cycle activity were generally greater in primary than in secondary forest soils. Efficiency of organic $\mathrm{C}$ use and the relative contribution of respiration and organic $\mathrm{C}$ to soil biomass were also greater in the primary forest. These trends corresponded with greater richness, biomass, and cover of total and leguminous plant species, greater volume of $P$. macroloba in primary stands, and greater density of $P$. macroloba in secondary stands. As cleared regions of former primary forest regenerate, $P$. macroloba is the important dominant $\mathrm{N}$-fixing tree and a critical driver of $\mathrm{C}, \mathrm{N}$, and $P$ recuperation and ecosystem recovery.
\end{abstract}

\section{Introduction}

Tropical forests originally covered up to $99 \%$ of the land in Costa Rica [1]. Approximately $90 \%$ of the original forests in Costa Rica have been destroyed in recent decades, and approximately $46 \%$ of the total area has been converted into cattle pasture [1,2]. In the Northern Zone of Costa Rica, four decades of deforestation have resulted in the loss of about $70 \%$ of the lowland forests [2-7]. The resulting fragmentation has yielded concern among regional scientists regarding whether the remaining primary forests will be able to regenerate at a rate matching the deforestation [7].

Today, tropical forest land is characterized by an expanding proportion of secondary forests [8]. As the area of the secondary forests grows at the cost of primary forests, the secondary forests will have to be managed and used in the future [9]. Rates of recovery for abandoned farmland in tropical areas are accelerated if prior land-use intensity was low, areas recovering are small in size, soils are fertile, and there are remnant forests nearby [10]. However, many areas cleared and used as pasture in Costa Rica have suffered such a severe deterioration of soils that forest successional processes are hindered. Instead of forests returning to the area, researchers are finding colonization of scrub growth and invasive grasses and ferns $[1,11]$. Therefore, Costa Rica has a great need for reforestation and assisted natural regeneration [12]. Indeed, attempts to remediate the effects of agricultural activities have resulted in implementation of a variety of restoration strategies, including development of an extensive array of secondary forests $[5,6,13-15]$.

Soils in secondary forests in the tropics are thought to follow a successional process of development during forest regeneration that parallels the increase in complexity of the vegetation community [16-19]. This process results in increases in the abundance and complexity of soil organic matter [20-26]. Greater amounts of nitrogen N fixation and ammonium oxidation are also thought to occur in these soils, as the forest develops greater density, diversity, and volume of leguminous vegetation during natural succession or following disturbance $[22,27-31]$. 
After tropical forests are cleared, plants with N-fixing root nodule symbionts are considered to be the principal pathway by which these secondary forests recuperate $\mathrm{N}$. These $\mathrm{N}$ fixing species restore soil fertility, stimulating the growth of other plant species and soil biomass development [30, 32, 33]. The increase in abundance and diversity of understory vegetation in forests also results in enhanced leaf litter quantity and quality in forest floor debris and production of more organic carbon (C), N, and phosphorus (P) through increased rates of decomposition and enhancement of the soil organic matter (e.g., [19, 34-44]). These activities can stimulate rhizodeposition and increased production of labile root-derived carbohydrates, further enhancing the microbial community [45-47]. It is also believed that as forest soils undergo succession, the fungal community becomes more complex $[48,49]$, including the shift from nitrophobic to nitrophilic fungal groups that conduct nitrification in acidic forest soils $[50,51]$.

Succession in lowland Neotropical secondary forests has been investigated for almost a century, but more work is needed which connects the below-ground nutrient dynamics with above-ground vegetation characteristics [52]. Research has shown an increase in above-ground biomass, and species diversity generally characterizes older forests, yet much less work has been done to examine below-ground processes that occur during tropical secondary succession [8]. For example, Chazdon et al. [53] discussed the rates of changes in vegetation occurring in secondary forests in Costa Rica following the original disturbance, but there were no connections made to below-ground nutrient cycle dynamics. Eaton et al. [44] showed that 25- and 30-year-old secondary forests in the region had developed a more complex soil microbial community and nutrient structure than the younger 15-year-old forest soils, but there was no connection with above-ground forest vegetation community composition and structure.

In 2001, the Costa Rican government established the 1,204,812 ha San Juan-La Selva Biological Corridor (SJLSBC) to help protect the Northern Zone ecosystems (http:// www.cct.or.cr/publicaciones/Estrategia-Exitosa-CBSS.pdf), the core conservation unit of which is the Maquenque National Wildlife Refuge (MNWLR), which conserves the portion of the corridor with the highest percentage of forest cover. The MNWLR contains a patchwork of old growth (primary) forests and harvested forests with natural regrowth secondary forests. Pentaclethra macroloba (Willd.) Kuntze (Fabaceae) is the dominant $\mathrm{N}$-fixing tree in these Costa Rican hardwood forests and is thought to be important in $\mathrm{N}$ and $\mathrm{C}$ cycle dynamics, biomass enhancement, and forest succession $[54,55]$ and is presumed to be a fundamental early colo-nizing tree in these secondary forests. However, to date, there have been no studies that examine the role of this tree in succession of vegetation and nutrient dynamics in these Costa Rican secondary forests. It has recently been discovered that the root nodules of $P$. macroloba are associated with populations of Frankia spp., while Rhizobium spp. appear to colonize rhizosphere soils somewhat further from the root nodules [56]. The symbiotic association between these $\mathrm{N}$-fixing microorganisms and P. macroloba represents an essential mechanism for $\mathrm{N}$ availability in the acidic and infertile soils of the wet tropics of Costa Rica $[56,57]$.

This study was conducted in primary and secondary lowland wet forests of Costa Rica's MNWLR. The main objectives were (1) to compare the C, P, and N-cycle characteristics and the diversity and abundance of the leguminous vegetation in these forest stands and (2) to use these variables to begin to evaluate the role of $P$. macroloba in primary and secondary forest soil and successional processes. We hypothesized that we would find evidence to suggest that $P$. macroloba plays a greater role in secondary stands, having a greater effect on nutrient cycle dynamics, as these soils recover from disturbance, as compared to the primary stands, which have already undergone succession, and, consequently, would have greater complexity of vegetation and soil ecosystem conditions.

\section{Methods}

The study sites for this project were within the MNWLR located in the Northeast region of Costa Rica, about $15 \mathrm{~km}$ south of the Nicaraguan border (10.7151, -84.1697). During June of 2008, we established four $20 \mathrm{~m} \times 15 \mathrm{~m}\left(300 \mathrm{~m}^{2}\right)$ plots both in primary and secondary forests of MNWLR in areas where $P$. macroloba was present as the dominant $\mathrm{N}$-fixing tree for a total of eight $300 \mathrm{~m}^{2}$ plots. All habitats were once part of a single primary forest of the same terrain, soil type, and topography but have been managed differently in the past $~ 30$ years. The primary forests are upland forests typical of the region, which have not been disturbed in the known history of the area (covering at least 100 years). The secondary forests used in this study were part of this same upland forest but were cleared and have now been regenerating into secondary forests for 15 years.

2.1. Soil Investigation. In June of 2008 and 2009, we collected 20 randomly located $2 \mathrm{~cm}$ wide $\times 15 \mathrm{~cm}$ deep soil cores within each plot and composited for analysis over two consecutive days and sieved at field moist conditions through $8 \mathrm{~mm}$ mesh. Soils were held at ambient conditions to avoid temperature shock, and analysis was performed on field moist soils at the field station within 4 days of collection. The percent of the water by weight in the soil, $\mathrm{pH}$, and bulk density was determined at 10 randomly located sites within each plot. All nutrient and microbial activity data are combined results from the two years of sampling and have been adjusted for dry weight and bulk density of the soil and are presented as such.

The amount of ammonium $\left(\mathrm{NH}_{4}-\mathrm{N}\right)$, as an indicator of possible $\mathrm{N}$ fixation and organic $\mathrm{N}$ decomposition, nitrate $\left(\mathrm{NO}_{3}-\mathrm{N}\right)$, as an indicator of ammonium oxidation, and total mineral $\mathrm{N}(\mathrm{TMN})$ were determined following $2 \mathrm{M} \mathrm{KCl}$ extraction of $10 \mathrm{~g}$ of soil by the ammonium salicylate and cadmium reduction spectrophotometric methods, using a HACH DR 3200 spectrophotometer (Hach Company, Loveland, Colorado, 80539-0389). The TMN was calculated as the amounts of $\mathrm{NH}_{4}-\mathrm{N}$ and $\mathrm{NO}_{3}-\mathrm{N}$. Phosphate $\left(\mathrm{PO}_{4}\right)$ was measured after Bray 1 extraction (typically used in this region due to the low $\mathrm{pH}$ of these soils) from $2 \mathrm{~g}$ of soil using 
the molybdate reduction method and the HACH DR 3200 spectrophotometer.

Microbial biomass $\mathrm{C}\left(\mathrm{C}_{\text {mic }}\right)$ was determined by the fumigation-extraction method as the difference between $\mathrm{K}_{2} \mathrm{SO}_{4}$ extracted dissolved organic carbon (DOC) levels in ethanol-free chloroform-fumigated and unfumigated $10 \mathrm{~g}$ soil subsamples. The DOC levels were determined by dry combustion analysis at the CATIE labs in Turrialba, Costa Rica, using the methods of Anderson and Ingram [58] and an autoanalyzer (Alliance Instruments). The rate of respiration was determined as amount of $\mathrm{CO}_{2}$ released over a 1 hour period using a Qubit SR1LP Respiration system (Kingston, ON, Canada). From these, the microbial metabolic quotients $\left(\mathrm{qCO}_{2}\right.$, as a ratio of $\mathrm{CO}_{2}$ from respiration/ $\mathrm{C}_{\text {mic }}$ ) and the ratio of $\mathrm{C}_{\text {mic }} / \mathrm{DOC}$ were determined to estimate the efficiency of utilization of organic $\mathrm{C}[48,59]$. The lower the $\mathrm{qCO}_{2}$ and the greater the $\mathrm{Cmic} / \mathrm{DOC}$, the more efficient the microbial community is using organic $\mathrm{C}$ and is presumably converting more $\mathrm{C}$ into biomass, rather than releasing it as $\mathrm{CO}_{2}$ [48].

The recent approach of Blagodatskaya et al. [60] and Kuzyakov [61] was used to determine ratios of primary to secondary forest DOC, respiration, and biomass to estimate the relative contribution (RC) of these individual sources of $\mathrm{C}$ by habitat. Also following these methods, we combined the RC ratios of the biomass to respiration and biomass to DOC to provide a comparison of the level of contribution to biomass in these soils by habitat as a further indicator of C-use efficiency. Blagodatskaya et al. [60] and Kuzyakov [61] used these methods to estimate rate of $\mathrm{C}$ turnover in soils.

2.2. Vegetation Investigation. In June, 2010, vegetation studies were conducted within the same plots as had previously been used for soil collection. By conducting the vegetation analyses at a different time than the soil studies, the understory vegetation was not disturbed by what typically occurs during soil collection. Within each of these $20 \mathrm{~m} \times 15 \mathrm{~m}$ plots, we recorded the density of adult $P$. macroloba trees $(>2 \mathrm{~m}$ in height) and seedlings of young trees (in classes of $<1 \mathrm{~m}$ and $>1 \mathrm{~m})$. The diameter at breast height $(\mathrm{DBH})$ was recorded for all trees over $2 \mathrm{~m}$ in height. The height of each tree was calculated using the principle of triangulation with a clinometer, and each seedling or young tree was measured using a tape measure. Basal area of $P$. macroloba per hectare was calculated using the mean DBH of $P$. macroloba in each $300 \mathrm{~m}^{2}$ plot. Volume of $P$. macroloba trees over $2 \mathrm{~m}$ in height was calculated using the formula from Tilki and Fisher [57]

$$
\text { Volume index }=\mathrm{DBH}^{2} \times \text { height } \times 0.4 \mathrm{~m} \text {. }
$$

Tilki and Fisher [57] applied this calculation on $P$. macroloba in Costa Rica, yet the volume equation uses a general form factor of 0.4 regardless of species.

Within each plot, five nested $1 \mathrm{~m}^{2}$ quadrats were randomly placed to sample understory vegetation. Within each quadrat, percent cover and density were calculated for all plant species, and the total percent cover of the understory vegetation and overstory was estimated. Cover values were determined by layer, resulting in cover exceeding $100 \%$ in individual quadrats. Vegetative biomass for $1 \mathrm{~m}^{2}$ was calculated by clipping all above-ground understory vegetation in the quadrats, bringing it back to the lab, drying in an oven at $100^{\circ} \mathrm{C}$ for 24 hours and weighing the dried material. Samples of plants unidentifiable in the field were pressed and brought back to be identified by local experts using Manual de Plantas des Costa Rica (Hammel et al. manuscript in preparation). Currently accepted Latin names for species according to the Angiosperm Phylogeny Group III. Classification were found using http://www.theplantlist.org/.

The species richness and abundance of vegetation other than $P$. macroloba were recorded with the number of stems rooted within the $1 \mathrm{~m}^{2}$ quadrats as density. The density of each species in the five $1 \mathrm{~m}^{2}$ quadrats within a plot was combined to get a representative density for the larger plot area. We conducted Shannon-Weiner $\left(H^{\prime}\right)$ diversity analysis on both total plant species and separately for just leguminous species to compare diversity between the sites.

2.3. Data Analysis. Statistical analyses on these data were performed using the statistical software SPSS to determine if there were meaningful differences in the mean values of the parameters measured from the two different habitats. A weight of evidence approach was used involving the percent difference (PD), $t$-test $P$ values $(\alpha=0.10)$, and Hedge's $d$ effect size statistic $(>0.7$ is considered a large effect size difference). These measures were used as indicators of biologically meaningful differences between mean values of parameters measured, as recommended for analysis of small sample sizes by Di Stefano et al. [62]. Bivariate correlation analyses were also conducted to determine the strength of the relationships between vegetation and soil variables. For vegetative data, dependent variables compared between primary and secondary forests on the $300 \mathrm{~m}^{2}$ plot scale include number of $P$. macroloba seedlings, number of $P$. macroloba adults, $P$. macroloba seedling height (in classes of $<1 \mathrm{~m}$ and $>1 \mathrm{~m}$ and average), $P$. macroloba tree $\mathrm{DBH}$, and heights of the trees. Dependent variables pooled among the five $1 \mathrm{~m}^{2}$ quadrats in each plot included percent cover of overstory, understory, percent cover for each species, and density of each woody species and density of legumes (including $P$. macroloba) rooted in the quadrats, species richness and percent cover of legumes, and biomass.

\section{Results}

Indicators of $\mathrm{C}, \mathrm{N}$, and $\mathrm{P}$ cycle activity were generally greater in the primary forest than in the secondary forest. Soils of the primary forests had greater levels of $\mathrm{P}, \mathrm{NO}_{3}$, and TMN. The DOC levels and respiration rates were greater in the secondary forest soils, but the soil C biomass levels were greater in the primary forest soils (Table 1). Consistent with these findings, the indicators of C-use efficiency showed that the soils in the primary forest were likely converting more organic $\mathrm{C}$ into biomass, as the $\mathrm{qCO}_{2}$ values were less and the $\mathrm{C}$ biomass to $\mathrm{DOC}$ ratio was greater in the primary forest soils. The RC of primary forest soils DOC and $\mathrm{CO}_{2}$ (as respiration) in both habitats was far less than that 
TABLE 1: Comparison of the plants, nutrients, and microbial activity measured in primary and secondary forests with $P$. macroloba as the dominant N-fixing tree within the MNWLR of Costa Rica. The percent water in the soil (\% Water), pH, ammonium $\left(\mathrm{NH}_{4}\right.$; $\left.\mathrm{mg} / \mathrm{cc}\right)$, nitrate $\left(\mathrm{NO}_{3} ; \mathrm{mg} / \mathrm{cc}\right)$, total mineral $\mathrm{N}(\mathrm{TMN} ; \mathrm{mg} / \mathrm{cc})$, the percent mineral $\mathrm{N}$ as nitrate $\left(\%\right.$ as $\left.\mathrm{NO}_{3}\right)$, phosphate $(\mu \mathrm{g} / \mathrm{cc})$, dissolved organic $\mathrm{C}(\mathrm{DOC}$; $\mu \mathrm{g} / \mathrm{cc}$ ), respiration (resp.; $\mu \mathrm{g} \mathrm{CO} / \mathrm{cc} / \mathrm{h}$ ), soil C biomass $\left(\mathrm{C}_{\mathrm{mic}} ; \mu \mathrm{g} \mathrm{C} / \mathrm{cc}\right), \mathrm{qCO}_{2}$, and soil C biomass to dissolved organic $\mathrm{C}$ ratio $\left(\mathrm{C}_{\text {mic }} / \mathrm{DOC}\right)$ are presented as mean values with the standard deviation (SD). The percent differences in mean values (\% Diff), $t$-test $P$ values, and Hedge's $d$ effect size values are provided.

\begin{tabular}{|c|c|c|c|c|c|c|c|}
\hline & \multicolumn{2}{|c|}{ Secondary forest } & \multicolumn{2}{|c|}{ Primary forest } & \multicolumn{3}{|c|}{ Statistical analyses } \\
\hline & Mean & SD & Mean & $\mathrm{SD}$ & $\%$ Diff & $t$-test & Hedge's $d$ value \\
\hline \multicolumn{8}{|l|}{ Vegetative community } \\
\hline Veg. biomass & 387.44 & 99.35 & 830.07 & 542.30 & 114.47 & 0.159 & 1.086 \\
\hline Spp. richness & 18.75 & 4.86 & 25.75 & 4.57 & 37.33 & 0.081 & 1.417 \\
\hline Shrub cover $(\%)$ & 67.75 & 11.33 & 65.40 & 21.83 & 3.47 & 0.855 & 0.129 \\
\hline Overstory (\%) & 96.00 & 8.00 & 100.00 & 0.00 & 4.17 & 0.356 & 0.675 \\
\hline Legume species richness & 1.50 & 0.58 & 3.00 & 0.82 & 100.00 & 0.024 & 2.017 \\
\hline Legume density & 5.50 & 7.14 & 5.00 & 4.00 & 9.09 & 0.907 & 0.083 \\
\hline Legume $\%$ cover & 14.25 & 14.22 & 56.50 & 35.74 & 296.49 & 0.070 & 1.483 \\
\hline \multicolumn{8}{|l|}{ P. macroloba } \\
\hline Seedlings $(<1 \mathrm{~m})$ & 34.00 & 30.77 & 45.00 & 42.14 & 32.35 & 0.688 & 0.285 \\
\hline Seedlings $>1 \mathrm{~m}$ & 33.50 & 19.14 & 2.75 & 2.22 & 91.79 & 0.019 & 2.156 \\
\hline Mean young tree height $(\mathrm{m})$ & 1.08 & 0.24 & 0.61 & 0.71 & 43.45 & 0.010 & 0.842 \\
\hline Mean adult tree height (m) & 10.30 & 2.37 & 24.05 & 5.45 & 113.61 & 0.040 & 2.410 \\
\hline Adult tree density per $300 \mathrm{~m}^{2}$ & 39.50 & 8.35 & 5.25 & 2.87 & 86.71 & 0.000 & 5.240 \\
\hline $\mathrm{DBH}(\mathrm{cm})$ & 7.38 & 1.80 & 28.00 & 4.57 & 279.40 & 0.000 & 5.671 \\
\hline Volume $\left(\mathrm{m}^{3}\right)$ & 0.07 & 0.02 & 1.44 & 0.36 & 2049.25 & 0.000 & 5.140 \\
\hline \multicolumn{8}{|l|}{ Soil nutrients } \\
\hline $\mathrm{NH}_{4}$ & 4.44 & 0.32 & 4.80 & 0.46 & 8.11 & 0.246 & 0.725 \\
\hline $\mathrm{NO}_{3}$ & 0.63 & 0.15 & 1.47 & 0.22 & 132.96 & 0.001 & 3.586 \\
\hline TMN & 5.07 & 0.36 & 5.77 & 0.28 & 13.72 & 0.022 & 1.722 \\
\hline$\%$ as $\mathrm{NO}_{3}$ & 20.10 & 9.49 & 48.50 & 2.77 & 141.29 & 0.001 & 3.242 \\
\hline Phosphate & 9.08 & 6.57 & 47.15 & 20.70 & 419.27 & 0.013 & 1.978 \\
\hline$\%$ Water & 67.75 & 1.71 & 30.25 & 1.71 & 123.97 & 0.000 & 20.97 \\
\hline $\mathrm{pH}$ & 6.73 & 0.09 & 6.02 & 0.30 & 10.55 & 0.004 & 3.10 \\
\hline \multicolumn{8}{|l|}{ Microbial activity indicators } \\
\hline Resp & 4.98 & 0.84 & 1.71 & 0.41 & 65.66 & 0.000 & 3.948 \\
\hline $\mathrm{C}_{\text {mic }}$ & 217.30 & 21.70 & 403.80 & 63.70 & 85.83 & 0.002 & 3.127 \\
\hline $\mathrm{qCO}_{2}$ & 4.42 & 1.18 & 2.74 & 0.70 & 38.01 & 0.049 & 1.382 \\
\hline $\mathrm{C}_{\mathrm{mic}} / \mathrm{DOC}$ & 0.19 & 0.03 & 0.66 & 0.18 & 247.37 & 0.002 & 2.906 \\
\hline
\end{tabular}

of the secondary forest, but the RC of primary forest soils biomass was much greater than that of the secondary forest. A comparison of the combined ratios of the RC of the biomass to respiration and biomass to DOC between the primary and secondary forest soils showed greater than a 5-fold and 3 -fold contribution, respectively, in the primary forest soils (Table 2).

At the $300 \mathrm{~m}^{2}$ plot level, the number of $P$ macroloba young seedlings was not significantly different between the primary and secondary forests. The number of seedlings above $1 \mathrm{~m}$ in height was significantly higher in the secondary forest, as was the total density of adult $P$. macroloba in the study area. In the primary forest plots, however, adult P. macroloba was greater in height, $\mathrm{DBH}$, and volume than in the secondary forest (Table 1). The primary stands were characterized by a mean $P$. macroloba basal area of $2.09 \mathrm{~m}^{2} /$ ha, whereas the mean basal area of $P$. macroloba in the secondary stands was $0.148 \mathrm{~m}^{2} /$ ha.

With lower seedling establishment and density of $P$. macroloba in the primary forest, the role of $\mathrm{N}$ fixation may be filled by other species. When investigating understory plant diversity in the $1 \mathrm{~m}^{2}$ quadrats, we found greater richness, biomass, and percent cover of total and leguminous plant species as well as biomass in the primary forest. There were nine legume species in the primary forests, and all three of the species that occurred in the secondary forests (including P. macroloba) were also found in the primary forests (Table 3). There was a significant difference not only in the number of 
TABLE 2: Comparison of the relative contribution (RC) of soil dissolved organic carbon (DOC), carbon dioxide $\left(\mathrm{CO}_{2}\right)$, and microbial biomass (Biomass) within primary and secondary forests with $P$. macroloba as the dominant N-fixing tree within the MNWLR of Costa Rica. The difference in the RC values is expressed as the ratio of RC primary to RC secondary. The ratio of the RC values for biomass to $\mathrm{CO}_{2}$ and to DOC is given for both the primary and secondary forest soils. From these values, a comparison is given of the ratio of values biomass to $\mathrm{CO}_{2}$ and biomass to DOC, comparing the primary to secondary forest values.

\begin{tabular}{|c|c|c|c|c|}
\hline & Total & $\begin{array}{c}\mathrm{RC} \\
\text { primary }\end{array}$ & $\begin{array}{c}\mathrm{RC} \\
\text { secondary }\end{array}$ & $\begin{array}{l}\text { Difference in } \\
\text { RC, primary } \\
\text { to secondary }\end{array}$ \\
\hline DOC & 1773.89 & 0.35 & 0.65 & 0.55 \\
\hline $\mathrm{CO}_{2}$ & 6.69 & 0.25 & 0.75 & 0.34 \\
\hline Biomass & 621.04 & 0.65 & 0.35 & 1.86 \\
\hline \multicolumn{2}{|c|}{ Ratio of RC values } & Primary & Secondary & \\
\hline \multicolumn{2}{|c|}{ Biomass to $\mathrm{CO}_{2}$} & 2.55 & 0.47 & \\
\hline \multicolumn{2}{|c|}{ Biomass to DOC } & 1.83 & 0.54 & \\
\hline \multicolumn{5}{|c|}{ Ratio of RC comparing primary to secondary forest stands } \\
\hline \multicolumn{2}{|c|}{ Biomass to $\mathrm{CO}_{2}$} & \multicolumn{2}{|c|}{5.43} & \\
\hline \multicolumn{2}{|c|}{ Biomass to DOC } & \multicolumn{2}{|c|}{3.38} & \\
\hline
\end{tabular}

TABLE 3: Leguminous species present in secondary and primary forest stands in the $5 \mathrm{~m}^{2}$ nested quadrat sampling area. Density and proportion of the species $\left(P_{i}\right)$ to total legume density are shown.

\begin{tabular}{|c|c|c|c|c|}
\hline \multirow{2}{*}{ Species } & \multicolumn{2}{|c|}{ Secondary forest } & \multicolumn{2}{|c|}{ Primary forest } \\
\hline & $\begin{array}{l}\text { Density } \\
\text { per } 5 \mathrm{~m}^{2}\end{array}$ & $P_{i}$ & $\begin{array}{l}\text { Density } \\
\text { per } 5 \mathrm{~m}^{2}\end{array}$ & $P_{i}$ \\
\hline $\begin{array}{l}\text { Dialium guianense (Aubl.) } \\
\text { Sandwith }\end{array}$ & 12 & 0.55 & 1 & 0.05 \\
\hline $\begin{array}{l}\text { Dipteryx panamensis (Pittier) } \\
\text { Record and Mell }\end{array}$ & 0 & 0.00 & 1 & 0.05 \\
\hline Dussia sp. & 0 & 0.00 & 1 & 0.05 \\
\hline Inga sp. & 1 & 0.05 & 3 & 0.15 \\
\hline Inga cocleensis Pittier & 0 & 0.00 & 1 & 0.05 \\
\hline Inga thibaudiana DC. & 0 & 0.00 & 1 & 0.05 \\
\hline P. macroloba (Willd.) Kuntze & 9 & 0.41 & 10 & 0.50 \\
\hline $\begin{array}{l}\text { Swartzia costaricensis (Britton) } \\
\text { N. Zamora }\end{array}$ & 0 & 0.00 & 1 & 0.05 \\
\hline Zygia sp. & 0 & 0.00 & 1 & 0.05 \\
\hline
\end{tabular}

leguminous species in the primary versus secondary forest stands, but also in the percent cover of the quadrats that these species occupied (Table 1). It was not confirmed through this study if these legumes had $\mathrm{N}$-fixing nodules, and since some were not identified to the species level, it is not possible to find existing literature regarding the identity of $\mathrm{N}$-fixing symbionts for each species.

The Shannon-Weiner index confirmed the higher diversity of legume species in the primary forest $\left(H^{\prime}=1.68\right)$ when compared to the secondary forest $\left(H^{\prime}=0.84\right)$. Total plant species richness was also higher in the primary forest stands (total of 52 species over the surveyed $1,200 \mathrm{~m}^{2}$ of primary forest) than the secondary stands (total of 43 species over the surveyed $1,200 \mathrm{~m}^{2}$ of secondary forest). For all species in the sampled area of the primary forest, $H^{\prime}=3.23$ and in the secondary forest $H^{\prime}=2.94$.

Correlation analysis showed that a greater volume of $P$. macroloba and percent cover of leguminous vegetation in the primary forests was correlated with a general enhancement of the indicators of microbial activity in the $\mathrm{C}, \mathrm{N}$, and $\mathrm{P}$ cycles. The number of young $P$. macroloba $>1 \mathrm{~m}$ and the overall height of the seedlings decreased with an increase in P. macroloba DBH $(r=0.833-0.883 ; P=0.010-0.004)$, height $(r=0.833-0.895 ; P=0.003-0.010)$, and volume $(r=0.760-0.827 ; P=0.011-0.029)$. Percent of the leguminous cover increased with an increase in $P$. macroloba DBH ( $r=0.694 ; P=0.056)$, height $(r=0.566 ; P=0.144)$, volume $(r=0.572 ; P=0.138)$, a decrease in the total number of $P$. macroloba trees $(r=0.663 ; P=0.073)$, and to a lesser degree, an increase in young tree height $(r=0.514 ; P=0.193)$ and a decrease in the number of $P$. macroloba seedlings $>1 \mathrm{~m}(r=$ 0.504 ; $P=0.203$ ). Also, the number of legumes present on the forest floor followed the same pattern of increasing with a decrease in the number of $P$. macroloba $(r=0.696 ; P=0.055)$ and an increase in the $P$. macroloba DBH $(r=0.598$; $P=0.117)$ and volume $(r=0.694 ; P=0.056)$. Increases in $P$. macroloba $\mathrm{DBH}$, height, and volume occurred with increases in soil nitrate $(r=0.746-0.840 ; P=0.009-0.033)$, total mineral N ( $r=0.650-0.778 ; P=0.023-0.081)$, the percent of $\mathrm{N}$ as nitrate $(r=0.873-0.913 ; P=0.002-0.005)$, the DOC $(r=0.803-0.903 ; P=0.002-0.016)$, the $\mathrm{C}$ biomass $(r=0.698-0.818 ; P=0.013-0.054)$, indicators of a more efficient use of soil C $\left(\mathrm{qCO}_{2}: r=0.608-0.693\right.$; $P=0.057-0.110$; C biomass per unit of DOC: $0.693-0.834$; $P=0.010-0.057)$, and with decreases in the respiration rate $(r=0.796-0.887 ; P=0.003-0.018)$.

\section{Discussion}

The importance of secondary forests is evident in Costa Rica, where nearly all primary lowland forests outside of protected areas are disturbed or converted by deforestation, and the amount of abandoned agricultural land continues to increase [1,9]. Trends found in this research can be used as indicators of success in tropical wet lowland forest management projects. In areas where agricultural land use has been abandoned and soils left degraded, Chazdon [12] points out that rehabilitation through planting of carefully selected trees can improve soil fertility. Additionally, Yang et al. [63] and Jin et al. [64] showed that as degraded tropical forests undergo succession naturally, the quality and quantity of the forest litter, root zone, and below-ground indicators of soil ecosystem conditions were more enhanced when compared to adjacent tree plantation soils. The current research emphasizes the role of $P$. macroloba as a pioneer tree species in the region, as we observed that $P$. macroloba is a key driver of succession in both above- and belowground communities. Similar to the findings of Yang et al. [63] and Jin et al. [64], we found that the increase in total and leguminous vegetation complexity was positively correlated with both the mass and volume of $P$. macroloba during forest 
succession, and the metrics were used to indicate enhanced soil ecosystem activities.

The presence of $P$. macroloba at high densities in secondary forests hastens the recovery of soil nutrients such as $\mathrm{N}$ and organic $\mathrm{C}$ and perhaps facilitates the development of a more complex $\mathrm{N}$-fixing vegetation community following disturbance. While the $P$. macroloba seedlings established at similar rates in the secondary and primary forests, we saw a change in leguminous species assemblages between successional stages, with $P$. macroloba as one of the only leguminous species in the secondary stands. It complements the work of Peña-Claros [65] who found that canopies of tropical secondary forests tend to be dominated by a small number of pioneer species, and as these pioneer tree species begin to die off, an increase in species diversity is expected because other tree species reach the canopy. Similarly, our primary forests were higher in plant diversity and had $P$. macroloba as one of several, albeit the dominant, N-fixing trees that occurred with an increased leguminous herbaceous population to enhance $\mathrm{N}$ and $\mathrm{C}$ cycle dynamics. For example, three species of the Inga genus were found in the sampled areas of the primary forest, and only one in the secondary forest sampling areas. This genus of tree may also be playing an important role in these primary forests, as they are believed to be critical ecosystem components within their range, serving as important sources of inorganic $N$ [66] and enhancing the quantity and quality of the soil organic $\mathrm{C}[67-70], \mathrm{N}$, and $\mathrm{P}[69,70]$. In addition, Inga species have been found to stimulate greater above-ground biomass development than other non-Inga species in their habitats $[68,71]$ and are thought to stimulate $C$ sequestration and long-term $\mathrm{N}$ accumulation $[67,68]$. It appears that both Inga spp. and $P$. macroloba along with the increased understory leguminous vegetation in the primary forest are playing the important role of enhancing soil ecosystem nutrient quantity and quality one would expect in these forests [30, 32, 33], while $P$. macroloba dominates this role in the secondary forests.

The primary forest soils had greater amounts of nitrate and a greater percent of the inorganic $\mathrm{N}$ as nitrate but similar levels of ammonium as the secondary forest soils, suggesting either greater or more efficient ammonium oxidizing activity in the primary forests. The enhanced microbial decomposition of organic matter associated with increases in successional stage of forests can also provide amine and other reduced $\mathrm{N}$ groups used for biomass development and also be used as an electron source for ammonium oxidizers [51]. These suggestions should be confirmed in future studies; however, they would be expected to occur in concert with the increasing vegetation complexity that occurs during secondary forest succession [22, 27-31].

The primary forest soils' greater amount of soil C biomass, contribution of $\mathrm{CO} 2$ and DOC into soil $\mathrm{C}$ biomass, rate of $\mathrm{C}$ turnover, and efficiency of organic $\mathrm{C}$ use further illustrate the complexity of the soil community in these older successional stage forests. These findings can be indicators of a more fungal dominant population decomposing the organic matter more efficiently for incorporation into the greater vegetation biomass [48, 59, 72, 73].
Greater levels of inorganic P, such as those found in the primary forest soils, have been associated with increased decomposition of the more complex and greater amounts of woody debris and litter $[26,36,37,41,42,74]$. It is of interest to note that the role of inorganic $\mathrm{P}$ in soil microbial activity in the tropical soils of this region remains unclear, as differences in observations have been reported from soils in similar forests of the Northern Zone of Costa Rica since 2002. Some researchers have shown that increases in inorganic $\mathrm{P}$ have been associated with increases in decomposition activity, soil ammonium oxidizing activity, rates of incorporation of inorganic $\mathrm{N}$ into cells, increased efficiency of $\mathrm{C}$ use and soil biomass development, and stimulation of the fungal community activity $[19,38-40,73,75,76]$. Others have found the opposite relationship $[44,77,78]$. A pattern similar to the first scenario was observed in the primary forests in the current study, as the increased soil biomass development and increased C-use efficiency were associated with much greater levels of inorganic $\mathrm{C}$ and a more complex vegetation community in the primary forests. More work is clearly needed to understand the role of $\mathrm{P}$ in microbial biomass development in these soils.

The correlation analyses conducted on the data from this study showed that as the forests get older, there are fewer $P$. macroloba trees, which, not surprisingly, are larger and make up a greater amount of the volume in the forests. Along with this increase in size of these trees, there is a corresponding increase in the number and percent cover of legume species in the understory. These differences in vegetation structure corresponded with increased values of the indicators of microbial activity associated with the $\mathrm{C}$ and $\mathrm{N}$ cycles, and an enhanced efficiency of the use of the organic $C$ by the soil biota $[48,52,79]$. Thus, it appears that while the greater density of younger $P$. macroloba is important in the $\mathrm{C}, \mathrm{N}$, and $\mathrm{P}$ recuperation of the earlier stages of secondary forest regeneration, perhaps this role shifts to the more diverse leguminous understory vegetation in the older forests. It would be valuable to study the different ages of secondary forests in the region to confirm that this shift does occur and determine at what age of secondary forest it takes place.

The patterns observed in the current study are consistent with what has been found elsewhere when comparing younger forests recovering from disturbance with more established primary or old growth forests. The increased amount of woody debris, litter, and leguminous vegetation that develops in the older forests is associated with an enhanced microbial community, which, typically, produces an accumulation of inorganic $\mathrm{N}$ and $\mathrm{P}$ nutrients and organic matter. These processes ultimately result in an increased efficiency in the use of the organic matter and biomass development [36, 37, 48, 59, 78-81].

\section{Conclusions}

Despite the limited dataset in this preliminary study, we did find that these primary and secondary lowland tropical wet forest stands differ in both their above-ground diversity and below-ground activities. We found support of our hypothesis 
that $P$. macroloba is critical for soil nutrient recovery in secondary forest stands as the primary N-fixing species. Future research conducted by the authors will investigate competitive relationships between plant species in this region and study whether the replacement of $P$. macroloba by other leguminous species in the older growth forests is by virtue of its inability to outcompete these species in areas in later successional stages. We have begun to expand this research to include additional series from earlier and midsuccession.

More studies such as this one are needed to understand the connections between below-ground activities and vegetative biomass and diversity in tropical forests. Such research demonstrates how pioneer species and other key groups affect the development of secondary forests into older stage forests and can be used to develop management strategies for recuperating soil nutrients in such degraded tropical lands. It appears that $P$. macroloba is an important pioneer species in forest recovery that is playing this role but is also a part of a more complex system of $\mathrm{N}$-fixing vegetation that develops in the primary forests that is associated with increased soil microbial activity, production of inorganic $\mathrm{P}$, and driving the conversion of both the $\mathrm{N}$ and $\mathrm{C}$ into biomass development that is ultimately resulting in a more efficient use of the organic material generated in these older forest soils.

Increasingly, researchers and land managers are recognizing plantations and managed forests as important tools for restoration of abandoned tropical pasturelands that can support diverse plant communities in addition to accomplishing economic objectives [81-83]. Plantations or managed forests with $P$. macroloba can be used to catalyze successional processes and have been found to sustain high plant diversity and organic carbon [83]. Our findings illustrate the fundamental role that $P$. macroloba plays in nutrient cycling in early successional forests. Restoration that supports either existing P. macroloba recruitment or adds this species to a site from which it has been extirpated can provide a method of minimum intervention that removes successional impediments. Our research suggests thata high density of $P$. macroloba in degraded lowland tropical forests may initiate a selfrepair process that will lead toward a properly functioning ecosystem in which nutrient cycling is efficiently performed by a greater diversity of leguminous vegetation in the later successional stages.

\section{Conflict of Interests}

There is no conflict of interests between the authors of this paper and companies used for analysis (Hach Company, Loveland, Colorado, and IBM SPSS statistical software, Armonk, NY, USA).

\section{Acknowledgments}

This work was supported by the National Science Foundation Research Experiences for Undergraduates Program (Grant no. 1034896) and the Kean University Office of Research and Sponsored Programs. The authors are very grateful to the staff of Laguna Del Lagarto Lodge for hosting them when they conducted this research and to Orlando Vargas (Organization of Tropical Studies, La Selva Station) and Nelson Zamora (Instituto Nacional de Biodiversidad) for assisting with plant identification. They also thank Kate Niemiera, Katie McGee, Ashley Casimir, Caitlin Looby, Brandon Nwobu, and Dana D'Angelo for their assistance in the field and laboratory.

\section{References}

[1] A. C. Leopold, R. Andrus, A. Finkeldey, and D. Knowles, "Attempting restoration of wet tropical forests in Costa Rica," Forest Ecology and Management, vol. 142, no. 1-3, pp. 243-249, 2001.

[2] G. A. Sánchez-Azofeifa, R. C. Harriss, and D. L. Skole, "Deforestation in Costa Rica: a quantitative analysis using remote sensing imagery," Biotropica, vol. 33, no. 3, pp. 378-384, 2001.

[3] S. A. Sader and A. T. Joyce, "Deforestation rates and trends in Costa Rica, 1940 to 1983," Biotropica, vol. 20, no. 1, pp. 11-19, 1988.

[4] G. A. Sánchez-Azofeifa, G. Daily, A. Pfaff, and C. Busch, "Integrity and isolation of Costa Rica's national parks and biological reserves: examining the dynamics of land cover change," Biological Conservation, vol. 109, no. 1, pp. 123-135, 2003.

[5] G. Monge, O. Chassot, R. Lopez, and H. Chaves, Justificación Biológica Para el Establecimiento del Propuesto Parque Nacional Maquenque. Corredor Biológico San Juan-La Selva, Corredor Biológico San Juan-La Selva, Centro Científico Tropical, San José, Calif, USA, 2002.

[6] G. Monge, O. Chassot, G. Powell, S. Palminteri, U. Aleman, and P. Wright, "Ecología de la lapa verde (Ara ambigua) en Costa Rica," Zeledonia, vol. 7, pp. 4-12, 2003.

[7] O. Chassot, G. Monge, G. Powell, P. Wright, and S. Palminteri, Un Proyecto del Corredor Biológico Mesoamericano Para la Conservación de la Lapa verde y su Entorno, Corredor Biológico San Juan-La Selva, Centro Científico Tropical, San José, Calif, USA, 2005.

[8] F. Q. Brearley, "Below-ground secondary succession in tropical forests of Borneo," Journal of Tropical Ecology, vol. 27, no. 4, pp. 413-420, 2011.

[9] G. Guggenberger and W. Zech, "Soil organic matter composition under primary forest, pasture, and secondary forest succession, Region Huetar Norte, Costa Rica," Forest Ecology and Management, vol. 124, no. 1, pp. 93-104, 1999.

[10] R. L. Chazdon, "Tropical forest recovery: legacies of human impact and natural disturbances," Perspectives in Plant Ecology, Evolution and Systematics, vol. 6, no. 1-2, pp. 51-71, 2003.

[11] J. Kuusipalo, G. Adjers, Y. Jafarsidik, A. Otsamo, K. Tuomela, and R. Vuokko, "Restoration of natural vegetation in degraded Imperata cylindrica grassland: understorey development in forest plantations," Journal of Vegetation Science, vol. 6, no. 2, pp. 205-210, 1995.

[12] R. L. Chazdon, "Beyond deforestation: restoring forests and ecosystem services on degraded lands," Science, vol. 320, no. 5882, pp. 1458-1460, 2008.

[13] M. Oelbermann, R. Paul Voroney, and A. M. Gordon, "Carbon sequestration in tropical and temperate agroforestry systems: a review with examples from Costa Rica and southern Canada," Agriculture, Ecosystems and Environment, vol. 104, no. 3, pp. 359-377, 2004.

[14] O. Chassot and G. Monge, Plan de Manejo del Refugio Nacional de Vida Silvestre Mixto Maquenque, 2006-2010. Ciudad Quesada, Alajuela, Costa Rica, Área de Conservación Arenal Huetar 
Norte (ACAHN), Sistema Nacional de Áreas de Conservación (SINAC), Ministerio del Ambiente y Energía (MINAE), Centro Científico Tropical (CCT), 2006.

[15] J. Schelhas and G. A. Sánchez-Azofeifa, "Post-frontier forest change adjacent to Braulio Carrillo National Park, Costa Rica," Human Ecology, vol. 34, no. 3, pp. 407-431, 2006.

[16] W. J. Parton, D. S. Schimel, C. V. Cole, and D. S. Ojima, "Analysis of factors controlling soil organic matter levels in Great Plains grasslands," Soil Science Society of America Journal, vol. 51, no. 5, pp. 1173-1179, 1987.

[17] G. Guggenberger, B. T. Christensen, and W. Zech, "Landuse effects on the composition of organic matter in particlesize separates of soil: I.Lignin and carbohydrate signature," European Journal of Soil Science, vol. 45, no. 4, pp. 449-458, 1994.

[18] W. Zech and I. Kögel-Knabner, "Patterns and regulation of organic matter transformation in soils: litter decomposition and humification," in Flux Control in Biological Systems, E. D. Schulze, Ed., pp. 303-334, Academic Press, New York, NY, USA, 1994.

[19] M. A. Bradford, N. Fierer, and J. F. Reynolds, "Soil carbon stocks in experimental mesocosms are dependent on the rate of labile carbon, nitrogen and phosphorus inputs to soils," Functional Ecology, vol. 22, no. 6, pp. 964-974, 2008.

[20] C. C. Rhoades, G. E. Eckert, and D. C. Coleman, "Soil carbon differences among forest, agriculture, and secondary vegetation in lower montane Ecuador," Ecological Applications, vol. 10, no. 2, pp. 497-505, 2000.

[21] W. L. Silver, R. Ostertag, and A. E. Lugo, "The potential for carbon sequestration through reforestationof abandoned tropical agricultural and pasture lands," Restoration Ecology, vol. 8, no. 4, pp. 394-407, 2000.

[22] T. R. Feldpausch, M. A. Rondon, E. C. M. Fernandes, S. J. Riha, and E. Wandelli, "Carbon and nutrient accumulation in secondary forests regenerating on pastures in central Amazonia," Ecological Applications, vol. 14, no. 4, pp. S164-S176, 2004.

[23] E. M. Veenendaal and M. D. Swaine, "Limits to tree species distributions in lowland tropical rainforests," in Dynamics of Tropical Communities, pp. 163-191, Blackwell, Oxford, UK, 1998.

[24] R. Condit, S. P. Hubbell, and R. B. Foster, "Mortality rates of 205 neotropical tree and shrub species and the impact of a severe drought," Ecological Monographs, vol. 65, no. 4, pp. 419-439, 1995.

[25] L. Poorter and Y. Hayashida-Oliver, "Effects of seasonal drought on gap and understorey seedlings in a Bolivian moist forest," Journal of Tropical Ecology, vol. 16, no. 4, pp. 481-498, 2000.

[26] B. M. J. Engelbrecht and T. A. Kursar, "Comparative droughtresistance of seedlings of 28 species of co-occurring tropical woody plants," Oecologia, vol. 136, no. 3, pp. 383-393, 2003.

[27] F. L. Walley, C. Van Kessel, and D. J. Pennock, "Landscape-scale variability of $\mathrm{N}$ mineralization in forest soils," Soil Biology and Biochemistry, vol. 28, no. 3, pp. 383-391, 1996.

[28] B. T. Shaffer, F. Widmer, L. A. Porteous, and R. J. Seidler, "Temporal and spatial distribution of the nifH gene of N2 fixing bacteria in forests and clearcuts in Western Oregon," Microbial Ecology, vol. 39, no. 1, pp. 12-21, 2000.

[29] M. S. Booth, J. M. Stark, and E. Rastetter, "Controls on nitrogen cycling in terrestrial ecosystems: a synthetic analysis of literature data," Ecological Monographs, vol. 75, no. 2, pp. 139157, 2005.
[30] C. Gehring, P. L. G. Vlek, L. A. G. De Souza, and M. Denich, "Biological nitrogen fixation in secondary regrowth and mature rainforest of central Amazonia," Agriculture, Ecosystems and Environment, vol. 111, no. 1-4, pp. 237-252, 2005.

[31] K. L. Sahrawat, "Factors affecting nitrification in soils," Communications in Soil Science and Plant Analysis, vol. 39, no. 9-10, pp. 1436-1446, 2008.

[32] M. R. Guariguata and R. Ostertag, "Neotropical secondary forest succession: changes in structural and functional characteristics," Forest Ecology and Management, vol. 148, no. 1-3, pp. 185-206, 2001

[33] J. D. Nichols, M. E. Rosemeyer, F. L. Carpenter, and J. Kettler, "Intercropping legume trees with native timber trees rapidly restores cover to eroded tropical pasture without fertilization," Forest Ecology and Management, vol. 152, no. 1-3, pp. 195-209, 2001.

[34] R. Ostertag and S. E. Hobbie, "Early stages of root and leaf decomposition in Hawaiian forests: effects of nutrient availability," Oecologia, vol. 121, no. 4, pp. 564-573, 1999.

[35] S. E. Hobbie and P. M. Vitousek, "Nutrient limitation of decomposition in Hawaiian forests," Ecology, vol. 81, no. 7, pp. 1867-1877, 2000.

[36] D. A. McGrath, N. B. Comerford, and M. L. Duryea, "Litter dynamics and monthly fluctuations in soil phosphorus availability in an Amazonian agroforest," Forest Ecology and Management, vol. 131, no. 1-3, pp. 167-181, 2000.

[37] J. Campo, M. Maass, V. J. Jaramillo, A. Martinez-Yrizar, and J. Sarukhan, "Phosphorus cycling in a Mexican tropical dry forest ecosystem," Biogeochemistry, vol. 53, pp. 161-179, 2001.

[38] C. C. Cleveland, A. R. Townsend, and S. K. Schmidt, "Phosphorus limitation of microbial processes in moist tropical forests: evidence from short-term laboratory incubations and field studies," Ecosystems, vol. 5, no. 7, pp. 680-691, 2002.

[39] C. C. Cleveland, A. R. Townsend, B. C. Constance, R. E. Ley, and S. K. Schmidt, "Soil microbial dynamics in Costa Rica: seasonal and biogeochemical constraints," Biotropica, vol. 36, no. 2, pp. 184-195, 2004.

[40] C. C. Cleveland and A. R. Townsend, "Nutrient additions to a tropical rain forest drive substantial soil carbon dioxide losses to the atmosphere," Proceedings of the National Academy of Sciences of the United States of America, vol. 103, no. 27, pp. 10316-10321, 2006.

[41] T. E. Wood, D. Lawrence, and D. A. Clark, "Variation in leaf litter nutrients of a Costa Rican rain forest is related to precipitation," Biogeochemistry, vol. 73, no. 2, pp. 417-437, 2005.

[42] T. E. Wood, D. Lawrence, and D. A. Clark, "Determinants of leaf litter nutrient cycling in a tropical rain forest: soil fertility versus topography," Ecosystems, vol. 9, no. 5, pp. 700-710, 2006.

[43] C. B. Blackwood, M. P. Waldrop, D. R. Zak, and R. L. Sinsabaugh, "Molecular analysis of fungal communities and laccase genes in decomposing litter reveals differences among forest types but no impact of nitrogen deposition," Environmental Microbiology, vol. 9, no. 5, pp. 1306-1316, 2007.

[44] W. D. Eaton, E. Giles, and D. Barry, "Microbial community indicators of soil development in tropical secondary forests (Costa Rica)," Ecological Restoration, vol. 28, no. 3, pp. 236-238, 2010.

[45] E. Paterson, "Importance of rhizodeposition in the coupling of plant and microbial productivity," European Journal of Soil Science, vol. 54, pp. 741-750, 2003. 
[46] C. Nguyen, "Rhizodeposition of organic C by plants: mechanisms and controls," Agronomie, vol. 23, no. 5-6, pp. 375-396, 2003.

[47] E. Paterson and A. Sim, "Rhizodeposition and C-partitioning of Lolium perenne in axenic culture affected by nitrogen supply and defoliation," Plant and Soil, vol. 216, no. 1-2, pp. 155-164, 1999.

[48] T. H. Anderson, "Microbial eco-physiological indicators to assess soil quality," Agriculture, Ecosystems, and Environment, vol. 98, pp. 285-293, 2003.

[49] W. De Boer, L. B. Folman, R. C. Summerbell, and L. Boddy, "Living in a fungal world: impact of fungi on soil bacterial niche development," FEMS Microbiology Reviews, vol. 29, no. 4, pp. 795-811, 2005.

[50] J. Dighton, A. R. Tuininga, D. M. Gray, R. E. Huskins, and T. Belton, "Impacts of atmospheric deposition on New Jersey pine barrens forest soils and communities of ectomycorrhizae," Forest Ecology and Management, vol. 201, no. 1, pp. 131-144, 2004.

[51] M. Hayatsu, K. Tago, and M. Saito, "Various players in the nitrogen cycle: diversity and functions of the microorganisms involved in nitrification and denitrification," Soil Science and Plant Nutrition, vol. 54, no. 1, pp. 33-45, 2008.

[52] P. Kardol and D. A. Wardle, "How understanding abovegroundbelowground linkages can assist restoration ecology," Trends in Ecology and Evolution, vol. 25, no. 11, pp. 670-679, 2010.

[53] R. L. Chazdon, S. G. Letcher, M. Van Breugel, M. MartínezRamos, F. Bongers, and B. Finegan, "Rates of change in tree communities of secondary Neotropical forests following major disturbances," Philosophical Transactions of the Royal Society B, vol. 362, no. 1478, pp. 273-289, 2007.

[54] G. S. Hartshorn and B. Hammel, "Vegetation types and floristic patterns," in La Selva. Ecology and Natural History of a Neotropical Rain Forest, L. Mcdade, K. Bawa, H. Hespenheide, and G. S. Hartshorn, Eds., pp. 73-89, University of Chicago Press, Chicago, Ill, USA, 1994.

[55] T. L. Pons, K. Perreijn, C. Van Kessel, and M. J. A. Werger, "Symbiotic nitrogen fixation in a tropical rainforest: ${ }^{15} \mathrm{~N}$ natural abundance measurements supported by experimental isotopic enrichment," New Phytologist, vol. 173, no. 1, pp. 154-167, 2007.

[56] W. D. Eaton, C. Anderson, E. F. Saunders, J. B. Hauge, and D. Barry, "The impact of Pentaclethra macroloba on soil microbial nitrogen fixing communities and nutrients within developing secondary forests in the Northern Zone of Costa Rica," Tropical Ecology, vol. 53, no. 2, pp. 207-214, 2012.

[57] F. Tilki and R. F. Fisher, "Tropical leguminous species for acid soils: studies on plant form and growth in Costa Rica," Forest Ecology and Management, vol. 108, no. 3, pp. 175-192, 1998.

[58] J. M. Anderson and J. S. I. Ingram, "Colorimetric determination of ammonium," in Tropical Soil Biology and Fertility, A Handbook of Methods, J. M. Anderson and J. S. I. Ingram, Eds., pp. 73-74, CAB International, Wallingford, UK, 2nd edition, 1993.

[59] M. C. Moscatelli, A. Lagomarsino, S. Marinari, P. De Angelis, and S. Grego, "Soil microbial indices as bioindicators of environmental changes in a poplar plantation," Ecological Indicators, vol. 5, no. 3, pp. 171-179, 2005.

[60] E. Blagodatskaya, T. Yuyukina, S. Blagodatsky, and Y. Kuzyakov, "Turnover of soil organic matter and of microbial biomass under C3-C4 vegetation change: consideration of ${ }^{13} \mathrm{C}$ fractionation and preferential substrate utilization," Soil Biology and Biochemistry, vol. 43, no. 1, pp. 159-166, 2011.
[61] Y. Kuzyakov, "How to link soil C pools with $\mathrm{CO}_{2}$ fluxes?" Biogeosciences, vol. 8, no. 6, pp. 1523-1537, 2011.

[62] J. Di Stefano, F. Fidler, and G. Cumming, "Effect size estimates and confidence intervals: an alternative focus for the presentation and interpretation of ecological data," in New Trends in Ecology Research, A. R. Burk, Ed., pp. 71-102, Nova Science, New York, NY, USA, 2005.

[63] K. Yang, J. Zhu, M. Zhang, Q. Yan, and O. J. Sun, "Soil microbial biomass carbon and nitrogen in forest ecosystems of Northeast China: a comparison between natural secondary forest and larch plantation," Journal of Plant Ecology, vol. 3, no. 3, pp. 175$182,2010$.

[64] H. Jin, O. J. Sun, and J. Liu, "Changes in soil microbial biomass and community structure with addition of contrasting types of plant litter in a semiarid grassland ecosystem," Journal of Plant Ecology, vol. 3, no. 3, pp. 209-217, 2010.

[65] M. Peña-Claros, "Changes in forest structure and species composition during secondary forest succession in the Bolivian Amazon," Biotropica, vol. 35, no. 4, pp. 450-461, 2003.

[66] B. Lojka, D. Preininger, J. Lojkova, J. Banout, and Z. Polesny, "Biomass growth and farmer knowledge of Inga edulis in Peruvian Amazon," Agricultura Tropica y Subtropica, vol. 38, pp. 44-51, 2005.

[67] K. A. Oglesby and J. H. Fownes, "Effects of chemical composition on nitrogen mineralization from green manures of seven tropical leguminous trees," Plant and Soil, vol. 143, no. 1, pp. 127132, 1992

[68] H. A. Leblanc, R. L. McGraw, P. Nygren, and C. L. Roux, "Neotropical legume tree Inga edulis forms $\mathrm{N}_{2}$-fixing symbiosis with fast-growing Bradyrhizobium strains," Plant and Soil, vol. 275, no. 1-2, pp. 123-133, 2005.

[69] B. Lojka, J. Lojkova, J. Banout, Z. Polesny, and D. Preininger, "Performance of an improved fallow system in the Peruvian Amazon-modelling approach," Agroforestry Systems, vol. 72, no. 1, pp. 27-39, 2008.

[70] L. T. Szott and C. A. Palm, "Nutrient stocks in managed and natural humid tropical fallows," Plant and Soil, vol. 186, no. 2, pp. 293-309, 1996.

[71] A. Lawrence, T. D. Pennington, M. R. Hands, and R. A. Zúniga, "Inga: high diversity in the neotropics," in Nitrogen Fixing Trees for Acid Soils, D. O. Evans and L. T. Szott, Eds., Proceeding of Workshop, pp. 130-141, Turrialba, San José, Calif, USA, 1995.

[72] G. S. Griffith and R. D. Bardgett, "Influence of resource unit distribution and quality on the activity of soil fungi in a particulate medium," New Phytologist, vol. 148, no. 1, pp. 143151,2000

[73] W. D. Eaton, S. McDonald, M. Roed, K. L. Vandecar, J. B. Hauge, and D. Barry, "A comparison of nutrient dynamics and microbial community characteristics across seasons and soil types in two different old growth forests in costa rica," Tropical Ecology, vol. 52, no. 1, pp. 35-48, 2011.

[74] M. I. Daws, D. F. R. P. Burslem, L. M. Crabtree, P. Kirkman, C. E. Mullins, and J. W. Dalling, "Differences in seed germination responses may promote coexistence of four sympatric Piper species," Functional Ecology, vol. 16, no. 2, pp. 258-267, 2002.

[75] V. J. Allison, L. M. Condron, D. A. Peltzer, S. J. Richardson, and B. L. Turner, "Changes in enzyme activities and soil microbial community composition along carbon and nutrient gradients at the Franz Josef chronosequence, New Zealand," Soil Biology and Biochemistry, vol. 39, no. 7, pp. 1770-1781, 2007.

[76] A. F. Cruz, C. Hamel, K. Hanson, F. Selles, and R. P. Zentner, "Thirty-seven years of soil nitrogen and phosphorus fertility 
management shapes the structure and function of the soil microbial community in a Brown Chernozem," Plant and Soil, vol. 315, no. 1-2, pp. 173-184, 2009.

[77] M. E. McGroddy, T. Daufresne, and L. O. Hedin, "Scaling of C:N:P stoichiometry in forests worldwide: implications of terrestrial redfield-type ratios," Ecology, vol. 85, pp. 2390-2401, 2004.

[78] L. Schewendenmann and E. Veldkamp, "Long-term $\mathrm{CO}_{2}$ production from deeply weathered soils of a tropical rain forest: evidence for a potential positive feedback to climate warming," Global Change Biology, vol. 12, no. 10, pp. 1878-1893, 2006.

[79] J. M. Talbot, S. D. Allison, and K. K. Treseder, "Decomposers in disguise: mycorrhizal fungi as regulators of soil $\mathrm{C}$ dynamics in ecosystems under global change," Functional Ecology, vol. 22, no. 6, pp. 955-963, 2008.

[80] K. Arunachalam, A. Arunachalam, R. S. Tripathi, and H. N. Pandey, "Dynamics of microbial population during the aggradation phase of a selectively logged subtropical humid forest in north-east India," Tropical Ecology, vol. 38, no. 2, pp. 333-341, 1997.

[81] W. D. Eaton, "Microbial and nutrient activity in soils from three different subtropical forest habitats in belize, Central America before and during the transition from dry to wet season," Applied Soil Ecology, vol. 16, no. 3, pp. 219-227, 2001.

[82] R. Butler, F. Montagnini, and P. Arroyo, "Woody understory plant diversity in pure and mixed native tree plantations at La Selva Biological Station, Costa Rica," Forest Ecology and Management, vol. 255, no. 7, pp. 2251-2263, 2008.

[83] F. S. Gilliam and M. Roberts, "Impacts of forest management on plant diversity," Ecological Applications, vol. 5, pp. 911-912, 1995. 

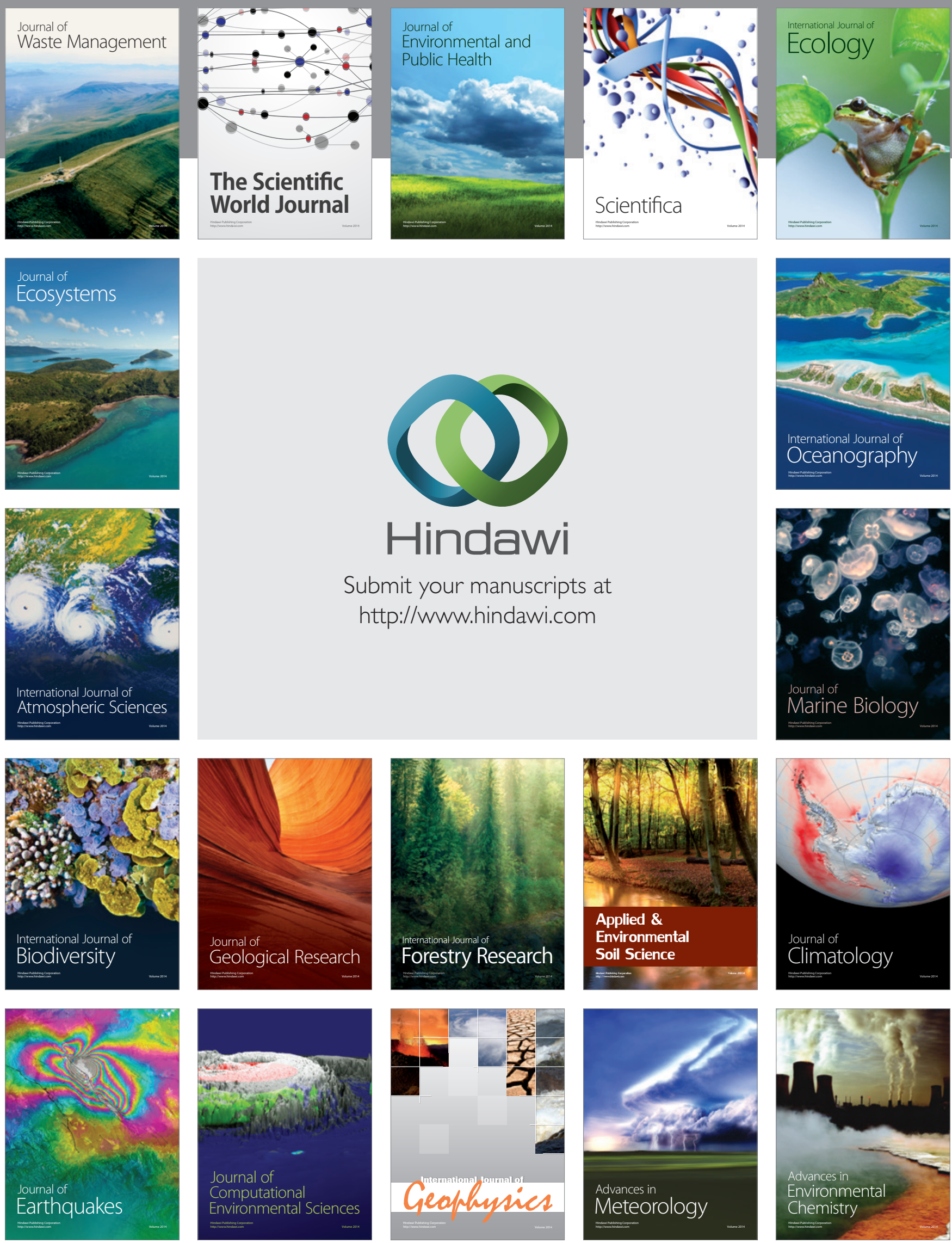